\title{
PROVIDING OF PSYCHOLOGICAL SAFETY OF PERSONNEL OF ORGANIZATION
}

УДК 159.9:62

DOI https://doi.org/10.32843/2663-

5208.2020.18.1.17

\section{Тиньков О.М.}

к.психол.н.

доцент кафедри психології

Національний аерокосмічний

університет імені М.Є. Жуковського

«Харківський авіаційний інститут»

\section{Долгополова О.В.}

к.психол.н.,

доцент кафедри психології

Національний аерокосмічний

університет імені М.Є. Жуковського

«Харківський авіаційний інститут»

\section{Фаворова К.М.}

к.психол.н.,

доцент кафедри психології

Національний аерокосмічний

університет імені М.Є. Жуковського

«Харківський авіаційний інститут» у статті розглядаються питання психологічної безпеки персоналу організації, які стають усе більш актуальними в сучасному суспільстві. Зумовлено це низкою таких причин: нестабільність економічної, політичної, соціальної ситуації; наявність стресогенних іпсихогенних дій різного ґенезу; слабка психологічна захищеність особи. Невдалий відбір персоналу зазвичай призводить до значних моральних і фрінансових втрат компанії. Сучасні керівники українських підприємств починають усвідомлювати невіддільну роль персоналу в успіху або невдачі їх організацій і вдаються до нових ефрективних методів відбору кадрів і періодичних перевірок працюючих співробітників. Основна увага у статті приділяється застосуванню таких методів підвищення безпеки персоналу, як психологічний відбір та перевірка працівників за допомогою поліграфра. у статті описано основні етапи проведення психологічного профресійного відбору, а саме: психологічний аналіз трудової діяльності; визначення професійно-важливих якостей; підбір методик психодіагностики; проведення процедури відбору; аналіз результатів; розробка рекомендацій щодо конкретних кандидатів; спостереження за колишніми кандидатами, які успішно пройшли відбір. Встановлюється послідовність проведення психологічного просресійного відбору, дається опис окремих процедур відбору. У статmі розглядаються питання роботи поліграсролога. у процесі роботи поліграсролога виникає багато питань, пов'язаних з використанням правових колізій. Наведено багато прикладів вирішення цих питань у світовому маситабі. У статті розкрито багато напрямів застосування поліграсру. Доведено, що, окрім виявлення брехні і винності, поліграфні обстеження також можуть сприяти виправданню несправедливо звинувачуваної людини, рішенню конфрліктних ситуацій між діловими партнерами і відновленню взаємної довіри. Практика використання «детектора брехні» комерційними структурами під час кадрового відбору і планових перевірок пращюючих співробітників показала, що цей метод дозволяє підприємству усунути багато джерел зайвих витрат. Дається аналіз поняття «психологічна безпека».

Ключові слова: профресійно-важливі якості, поліграфр, професійний відбір, понятття психологічної безпеки.
In the article the questions of psychological safety of personnel are examined organizations that become more actual in modern society. Conditioned it by a number of reasons: instability of economic, political, social situation; presence of стресогених and психогених actions of different genesis; weak psychological security of person. The unsuccessful selection of personnel usually results in the considerable moral and financial losses of company. The modern leaders of the Ukrainian enterprises begin to realize the inalienable role of personnel in success or failure of their organizations, and come running to the new effective methods of selection of personnels and periodic verifications of working employees. Basic attention in the article is spared to application of such methods of increase of safety of personnel, as a psychological selection and verification of workers by means of poligraf. The basic stages of realization of psychological professional selection are described in the article, namely: psychological analysis of labour activity; determination of professionallyimportant internalss; selection of methodologies of psychoactivator; realization of procedure of selection; analysis of results; development of recommendations is on concrete candidates; watching former candidates, that went a selection well. Set sequence of realization of psychological professional selection, description of separate procedures of selection is given. The questions of work of poligraf are examined in the article. In the process of work of poligraf there are many questions constrained with the use of legal collisions. Many examples of decision of these questions are made on a world scale. Many directions of application to poligraf are exposed in the article. It is wellproven that except the exposure of lie and guilt, poligrafs inspection also can assist acquittal of the unfairly accused man, decision of conflict situations between business partners and proceeding in a mutual trust. Practice of the use of "lie-detector" at a skilled selection and планових verifications of working employees showed business corporations, that this method allowed to the enterprise to remove many sources of superfluous charges. The analysis of concept "psychological safety" is given.

Key words: professionally-important internalss, poligraf, professional selection, concept of psychological safety.
Постановка проблеми. Перш ніж говорити про специфіку психологічної безпеки особистості, варто проаналізувати поняття «психологічна безпека» [5].

Поняття безпеки $€$ одним 3 найчастіше вживаних у сучасних дослідженнях. Вчені розглядають інформаційну, національну безпеку, безпеку життєдіяльності, праці тощо.
Психологічну безпеку людини визначають здебільшого як стан захищеності свідомості. У цьому й інших визначеннях безпеки не розкриваються сутнісний сенс категорії «психологічна безпека», що лежать в її основі. Між тим, потреба в освоєнні цього поняття в контексті рішення макроергономічних проблем дієздатності організації і забезпечення високої ефек- 
тивності професійної діяльності стає усе більш актуальною. Виникла об'єктивна необхідність вивчення, особливостей розвитку суб'єкта професійної діяльності, його професійно-особистісного потенціалу, збереження психічного і фізичного здоров'я з урахуванням ергономічних вимог - до параметрів, процесів, властивостей і умов діяльності, реалізація яких забезпечить досягнення необхідного рівня розвитку ергономічної системи.

Аналіз останніх досліджень і публікацій. Розглядаючи психологічну безпеку особистості, важливо підкреслити необхідність розгляду питань її захищеності. У такому разі необхідно говорити про всі сфери і міру їх розвитку як показник стійкості особистості до різних впливів ззовні і до власних негативних переживань. До таких сфер відносять зазвичай сферу пізнавальних процесів особистості, мотиваційну сферу, емоційну сферу, сферу міжособистісних стосунків, сферу ії росту (установки, ціннісні орієнтації, моральні норми і так далі), сферу професійної спрямованості і професійної компетентності [8, с. 10].

Психологічна безпека, що проявляється, зокрема, в адаптивності суб'єкта, в його готовності до ухвалення рішень, не лише додає значущості трудовій діяльності людини, але, як результат психічної активності суб'єкта, впливає на формування його особистісних якостей. При цьому одним з видів довільної психічної активності суб'єкта є психічна саморегуляція функціональних станів людини під час виконання складної професійної діяльності, що робить вплив на формування адаптивних властивостей суб'єкта і визначає ії ефективність, працездатність людини, його психологічну безпеку (Л.Г. Дика, В.В. Семенюк). Можуть бути небезпечними невдале професійне самовизначення, невідповідність психологічних і психофізичних особливостей людини ергономічним вимогам, стреси в професійній діяльності, умови праці, що не відповідають нормам безпеки, неадекватне відображеннячинників виробничого середовища [5;9].

Контроль і оцінка сильних і слабких сторін професіоналізму людини дозволяють надати ій необхідну допомогу, швидше виправити недоліки. Таким чином, зростає міра психологічної безпеки людини у рамках її професійної діяльності (безпека праці). Цим і визначаються завдання діагностики рівня професійного розвитку: вивчення професійної спрямованості і професійної ідентичності особистості, професійної придатності і компетентності, дослідження можливостей професійної готовності і професійної адаптації.

Кадрову безпеку в організації можна розглядати з різних позицій. 3 одного боку - це процес забезпечення поточної і потенційної захищеності персоналу організації від різноманітних загроз, під час відбору й адаптації персоналу, розвитку і кар'єрного росту співробітників, оцінки його ділових і особистісних характеристик і оплати праці, а також під час переміщення і звільнення 3 організації. Для персоналу в цьому разі основним джерелом загроз виступає працедавець, що грубо порушує права і гарантії працівників.

3 іншого боку, кадрову безпеку можна вибудовувати з погляду активного захисту, якого потребує сама організація. Йдеться про економічну безпеку, імідж і стійкий розвиток внутрішніх бізнес-процесів, про загрози, що створюються несанкціонованими свідомими або неусвідомленими діями персоналу цієї організації, які можуть вступати у сумнівні з погляду закону трудові відносини. Це може бути корупційна діяльність чиновників і осіб, що приймають рішення, зловживають своїм положенням. Працівники організації можуть вступати в змову, передавати секретну інформацію третім особам або використати їі не за призначенням. Окремі співробітники можуть здійснювати вербування фахівців, переманювати їх у конкуруючі організації. Успішні організації можуть піддаватися рейдерським захопленням, іншим видам насильницьких дій.

Ризики з боку персоналу виникають завжди і на усіх етапах роботи. У зв'язку з цим в організаціях створюють гнучку систему кадрової безпеки, здатну вчасно діагностувати небезпеку, що насувається, і своєчасно їй запобігти. В зв'язку з цим дуже важливо збудувати якісну взаємодію із службами управління персоналом в організації починаючи з етапу відбору і найму кадрів. У список «небезпечних» кандидатів включаються люди, чия робота в організації або їх подальше звільнення може викликати різні проблеми. Важливо не пропустити такого неблагонадійного співробітника не з погляду його професійної грамотності, а в аспекті його безпечного звільнення, що пов'язано з просочуванням інформації, наприклад, з посади головного бухгалтера. Мета служби кадрової безпеки - зменшення витрат на подальший відбір, щоб надалі вибирати тільки «безпечних» претендентів [10, с. 35].

Постановка завдання. Головним інструментом роботи служби кадрової безпеки $€$ тотальний контроль на усіх ділянках роботи персоналу. Це відеоспостереження, прослуховування телефонних розмов, контроль доступу і роботи комп'ютера, контроль використання робочого і вільного часу співробітників, переміщень, тобто контроль в процесі трудової діяльності і деякий час після звільнення співробітника. Природньо, що такі завдання мають бути узгоджені з законністю методів добування необхідної інформації. 
Виклад основного матеріалу дослідження. Відбір персоналу (рекрутінг), це процес виявлення найбільш придатних і підготовлених працівників з числа кандидатів на вакансію. Професійний («правильний») процес рекрутінгу складається з декількох етапів:

- планування потреби у персоналі;

- збір і узгодження заявок на відбір;

- бюджетування процесу,

- розміщення вакансії у відкритому доступі під час пошуку кандидатів,

- проведення співбесіди з кандидатом і лінійним керівником, а також отримання укладення за підсумками перевірки кандидата службою безпеки;

- підписання трудового договору [6, с. 20].

Для кожного працедавця відомий той факт, що своєчасний і якісний відбір персоналу збільшує прибуток організації і $€$ гарантією успішного функціонування бізнес-процесів.

Отже, погано організований відбір персоналу обертається для компанії такими проблемами, як висока плинність кадрів, низька корпоративна згуртованість співробітників і низька трудова дисципліна.

Психологічний відбір є одним з компонентів професійного відбору і припускає вибір кандидатів на основі оцінки їх професійно-важливих якостей (далі - ПВЯ). Оцінка ПВЯ конкретної людини робиться на основі вивчення кількісних і якісних показників в певному виді діяльності. Шляхом співвідношення показників продуктивності праці цієї людини з певними показниками інших осіб (професійно підготовлених, зайнятих тим же видом діяльності) можна з великою точністю охарактеризувати й оцінити його ПВЯ [7]. Така оцінка потрібна для проведення професійного психологічного відбору, який складається з таких етапів:

1. Психологічний аналіз трудової діяльності.

2. Визначення ПВЯ.

3. Підбір методик психодіагностики.

4. Власне проведення процедури відбору.

5. Аналіз результатів.

6. Розробка рекомендацій щодо конкретних кандидатів.

7. Спостереження за колишніми кандидатами, які успішно пройшли відбір. Аналіз їх діяльності на робочих місцях.

8. Внесення корекції (за необхідності) у будь-який з перерахованих етапів.

На першому етапі складають фотографію робочого часу фахівця з конкретної профеciї. Для цього притягуються професіонали, які виконують роль експертів. 3 їх допомогою проводиться хронометраж трудової діяльності в реальному масштабі часу або після її аудіозапису і відеозйомки. Це необхідно для визначення вагових коефіцієнтів психологічних якостей, які повинен мати фахівець [7].
На другому етапі за допомогою кореляційного аналізу визначають величину зв'язку між психологічними якостями, що мають найбільшу вагу (їх цифровими даними, отриманими шляхом тестування), і об'єктивними показниками якості професійної діяльності. Цими показниками можуть бути час і безпомилковість рішення професійних завдань.

Таким чином, перші два етапи є психограмою конкретного професіонала, яку використовують як еталонний набір ПВЯ під час відбору.

На третьому етапі відповідно до певних ПВЯ підбирають психодіагностичні методики. Їх кількість має бути оптимальною - до десяти штук, вони не повинні дублювати одна одну, вони мають бути апробовані (мати високу надійність і валідність) [7].

Четвертий етап складається із стандартних процедур. Кількість випробовуваних (за один сеанс) не повинна перевищувати 20 осіб, час проведення - не більше за 2-х годин.

На п'ятому і шостому етапах проводять психологічний і статистичний аналізи результатів тестування. Особливість полягає в тому, що статистичний аналіз повинен служити лише інструментом, а не основою для змістовних висновків. Рекомендації щодо конкретних кандидатів пишуть на доступному для замовника рівні складності [1, с. 36].

Після прийняття на роботу колишнього кандидата необхідно спостерігати за якістю його роботи. Це необхідно для можливої корекції будь-яких етапів відбору.

Невдалий відбір персоналу зазвичай призводить до значних моральних і фінансових втрат компанії. Сучасні керівники українських підприємств починають усвідомлювати невіддільну роль персоналу в успіху або невдачі їх організацій і вдаються до нових ефективних методів відбору кадрів і періодичних перевірок працюючих співробітників. Такі перевірки можуть здійснюватися за допомогою поліграфа [3, с. 10].

Працюючи спільно з відділом кадрів поліграфолог може провести:

1. Скринінгові перевірки (від англ. "screening" просіювати, перевіряти на благонадійність) найманого на роботу персоналу.

2. Періодичні перевірки працюючого персоналу.

3. Вибіркові та позапланові перевірки працюючого персоналу.

4. Перевірки персоналу в процесі службових розслідувань і розглядів.

За допомогою поліграфних перевірок ми можемо встановити та виявити:

а) спотворення біографічних даних;

б) благонадійність або лояльність;

в) істинні мотиви вступу на роботу (цілі, причини, стимули); 
г) психоемоційний фон, психопатичні риси, моральні аспекти, рівень самооцінки, сильні і слабкі сторони обстежуваного;

д) загальну мотиваційну спрямованість, ціннісну орієнтацію обстежуваного;

е) окремі індивідуальні особливості обстежуваного;

ж) наявність наркотичної і алкогольної залежності;

з) пристрасть до азартних ігор;

и) відомості про вчинені у минулому злочини і проступки;

к) зв'язки з кримінальними елементами;

л) наявність злочинних або злих намірів;

м) приховувані службові проступки;

н) наявність психічних або інших захворювань і відхилень;

о) незаконне володіння зброєю;

Окрімвиявленнябрехніівинності, поліграфні обстеження також можуть сприяти виправданню несправедливо звинувачуваної людини, вирішенню конфліктних ситуацій між діловими партнерами і відновленню взаємної довіри.

Практика використання «детектора брехні» комерційними структурами під час кадрового відбору і планових перевірок працюючих співробітників показала, що цей метод дозволить підприємству усунути багато джерел зайвих витрат, зокрема:

а) неефективність роботи персоналу;

б) високу плинність кадрів;

в) крадіжки продукції, що випускається;

г) витік конфіденційної інформації;

д) розкрадання технологій, розкриття комерційної таємниці;

е) застосування матеріально-фінансових ресурсів не за призначенням;

ж) такі злочини, як: підпал, вандалізм, вбивства, зґвалтування, фінансові крадіжки і тому подібне.

Найбільший досвід у використанні поліграфа в інтересах бізнесу накопичили США, що застосовують цей метод вже понад півстоліття. У цій країні в 80-і роки у сфері приватного підприємництва, за різними оцінками, щорічно здійснювалося близько 1,5 млн перевірок на поліграфі різного цільового призначення [2, с. 11].

3 метою комерційної безпеки спеціальні психофізичні дослідження (методи) використовуються зазвичай за трьома прикладними напрямами.

По-перше, це скринінгові методи перевірки найманого на службу персоналу. За оцінкою журналу Business Week, в середині 80-х років все більше число приватних компаній вико- ристало випробування на поліграфі як один з головних методів перевірки кандидатів, що приходять на роботу.

Другий напрям - випробування на поліграфі працюючого персоналу.

Третє - методи перевірки в процесі службових розслідувань.

Ефективність застосування перевірок на поліграфі по кожному з цих напрямів досить висока (упродовж десятиліть цей метод у кадрових цілях використовують Центральне розвідувальне управління, Агентство національної безпеки й інші федеральні відомства США [3, с. 96].

Експерти Конгресу США констатували, що злочини, що здійснюються в приватному секторі країни, щорічно оцінюються в 10 млрд доларів. Відтак очевидною комерційна рентабельність, яку забезпечують поліграфні перевірки як під час підбору кадрів, так і в процесі службових розслідувань.

Застосування поліграфа під час прийому кандидата на роботу в деяких країнах (наприклад, у Німеччині) заборонене навіть за наявності його згоди. Виняток становлять деякі специфічні сфери діяльності.

Також у США існує закон про захист працівників від перевірки на поліграфі. Це пояснюється тим, що така перевірка порушує людську гідність.

У законодавстві України використання поліграфа під час прийому на роботу не закріплене, хоча його застосовують і державні, і приватні організації (наприклад, банки й інші фінансові установи).

Подібна перевірка має позитивний вплив на кандидата, який розуміє серйозність організації, в якій він працюватиме [4, с. 44].

Примус з боку керівника до проходження перевірки на поліграфі під час прийому кандидата на роботу є неприпустимим.

Висновки з проведеного дослідження. Погано організований відбір персоналу обертається для компанії такими проблемами, як висока плинність кадрів, низька корпоративна згуртованість співробітників і низька трудова дисципліна. Комерційна рентабельність, яку забезпечують поліграфні перевірки як під час підбору кадрів, так і в процесі службових розслідувань, дуже висока. Подальше вивчення питань підвищення психологічної безпеки особистостіможебутиспрямованенадослідження контролю психологічного стану працівника за його мовним сигналом. Такі пристрої вже існують, однак потребують доопрацювання з огляду на зменшення похибки такої оцінки. 


\section{ЛІТЕРАТУРА:}

1. Бакшт К. Вербовка: альтернативный вариант подбора персонала / К. Бакшт. HR-portal. URL: http://hr-portal.ru/article/verbovka-alternativnyy-variantpodbora-personala. Дата обращения 29.08.2017.

2. Беляев С. Агрессивный рекрутинг: Партизанские методы подбора персонала. HR-portal. URL: http://hr-portal.ru/article/agressivnyy-rekrutingpartizanskie-metody-podbora-personala. Дата обращения 27.08.2017.

3. Бизнес-разведка: законные методы и запрещенные приемы. URL: http://hrportal.ru/article/biznesrazvedka-zakonnye-metody-i-zapreshchennye-priemy. Дата обращения 27.08.2017.

4. Королёва Н. Как быстро подобрать десятки или даже сотни сотрудников. Используйте для массового подбора нестандартные и действенные методы. Директор по персоналу. № 9. 2013. URL: http://e.hr-director.ru/article.aspx?aid=317825\&utm medium $=$ refer\&utm source $=$ e.hr-director.ru\&utm campaign=e.hrdirector_7Block\&utm_content=7 (дата обращения 02.08. 2017).
5. Пухарева Т.С. Психологическая безопасность и ее роль в профессиональном развитии личности. Психолог. № 2, 2016. С. 9-19.

6. Скрыль В.В. Методы отбора персонала на предприятии как инструмент реализации кадровой политики. URL: http://sci-article.ru/stat.php?i=1429596549 (дата обращения 27.08.2017).

7. Тиньков О.М., Фаворова К.М. Психофрізіологічні стани операторів автоматизованих систем управління повітряним рухом; Класичний приватний університет. Теорія і практика сучасної психології: зб. наук. пр. 2019. № 6. T. 1. С. 96-100. DOI https://doi.org/ 10.32840/2663-6026.2019.6-1.20.

8. Шлыкова Н.Л. Психологическая безопасность субъекта профессиональной деятельности. Тверь : Триада, 2004. 151 с.

9. Эксакусто Т.В. Обеспечение психологической безопасности личности с учетом развития и коррекции личностных свойств. Известия ТРТУ. Тематический выпуск «Психология и педагогика». Таганрог : Изд-во ТРТУ, 2006. №14 (69). С. 383-391.

10. Ющенко Д. Вербовка в бизнесе. Кадровик. Рекрутинг для кадровика. 2012. 210 с. 